\title{
Penamaan Menu Makanan di Bali
}

\author{
Pramita Fara Nuari \\ Pendidikan Bahasa dan Sastra Indonesia, Universitas Muhammadiyah Jember \\ pramitafaran@gmail.com
}

DOI: http://dx.doi.org/10.32528/bb.v5i1.3008

Diterima: 13-02-2020

Diterbitkan: 30-03-2020

\begin{abstract}
ABSTRAK
Penelitian ini bertujuan untuk mendiskripsikan mengenai proses penamaan yang dipakai dalam beberapa menu makanan yang difokuskan pada bakso halal dan pisang goreng di Bali, agar masyarakat dapat mengetahui sebab yang melatarbelakangi terjadinya penamaan menu makanan tersebut. Penelitian deskriptif kualitatif ini menggunakan penamaan berdasarkan penyebutan sifat khas, penemu dan pembuat, tempat asal, bahan, keserupaan, dan pemandekan. Data penelitian ini berupa foto atau screenshoot daftar menu atau banner makanan khusus bakso dan pisang goreng yang ada di cafe, warung, atau gerobak bakso. Sumber data penelitian ini adalah daftar nama-nama menu makanan, dengan menggunakan media sosial seperti google, facebook, dan instagram untuk mengetahui nama-nama menu makanan bakso dan pisang goreng yang ada di Bali, tepatnya di Ibu Kota Provinsi yaitu Denpasar. Tahap analisis data ada tiga yaitu : 1) tahap reduksi data, 2) tahap penyajian data, dan 3) tahap verification. Tahap reduksi yaitu penyediaan data dengan teknik pengumpulan data yaitu dokumentasi berupa foto atau screenshoot daftar menu makanan khusus bakso halal dan pisang goreng. Selanjutnya menggunakan metode simak - sadap catat - rekam dan teknik pilah unsur penentu. Penyajian data dengan menggunakan teknik analisis data metode padan yaitu metode referensial dan otografis. Ketiga tahap verification yaitu dengan memeriksa kembali data yang disajikan sehingga didapatkan hasil yang benar-benar valid. Pengujian kesahihan data dengan meningkatkan ketekunan dan triangulasi. Penamaan yang ditemukan dalam penelitian ini ada Sembilan yaitu peniruan bunyi, penyebutan bagian, penyebutan sifat khas, penemu dan pembuat, tempat asal, bahan, keserupaan, pemendekan, dan penamaan baru. Data penamaan menu makanan yang paling banyak digunakan yaitu berasal dari bahan dan keserupaan. Data penamaan menu makanan yang jarang digunakan yaitu peniruan bunyi, penyebutan bagian, penyebutan sifat khas, tempat asal, penemu dan pembuat, pemendekan, dan penamaan baru.
\end{abstract}

Kata Kunci : Penamaan; Menu makanan; Bali 


\begin{abstract}
This study aims to describe the process of naming used in some food menus that are focused on halal meatballs and fried bananas in Bali, so that people can know the reason behind the naming of the food menu. This descriptive qualitative research uses naming based on the mention of the specific characteristics, inventor and maker, place of origin, material, similarity, and stand. This research data in the form of photos or screenshoot menu lists or special food banners and fried bananas in cafes, food stalls, or meatball carts. The data source of this research is a list of food menu names, using social media such as Google, Facebook, and Instagram to find out the names of the fried meatballs and banana food menus in Bali, precisely in the Provincial Capital, Denpasar. There are three data analysis stages, namely: 1) the data reduction stage, 2) the data presentation stage, and 3) the verification phase. The reduction stage is the provision of data with data collection techniques, namely documentation in the form of photos or screenshots of a list of special halal meatballs and fried banana food menus. Furthermore, using the method of listening - tapping - note - record and sorting elements determinant. Presentation of data by using data analysis techniques in the equivalent method namely referential and autographic methods. The third stage of verification is to double-check the data presented to obtain truly valid results. Testing the validity of the data by increasing perseverance and triangulation. The names found in this study were nine namely imitation of sound, mention of parts, mention of characteristics, inventor and maker, place of origin, material, similarity, shortening, and new naming. The most used food menu naming data is derived from ingredients and similarity. Data on naming food menus that are rarely used are imitations of sounds, mention of parts, mention of specific characteristics, place of origin, inventor and maker, shortening, and new naming.
\end{abstract}

\title{
Keywords: Naming; Food Menu; Bali
}

\section{PENDAHULUAN}

Bahasa merupakan sistem lambang arbitrer yang dipergunakan suatu masyarakat untuk bekerjasama, berinteraksi dan mengidentifikasi diri (Kridalaksana dalam Aminudin, 2016, hal. 28). Oleh karena itu, bahasa merupakan unsur terpenting dalam kehidupan sehari-hari, karena tanpa adanya bahasa manusia tidak dapat berkomunikasi dengan baik. Bahasa tidak hanya sebagai alat untuk berinteraksi dengan manusia lain, tetapi juga untuk menyampaikan maksud, tujuan dan perasaannya. Sebagai alat komunikasi, bahasa merupakan unsur terpenting dalam proses komunikasi, baik dalam proses berbicara maupun proses belajar mengajar. Melalui bahasa manusia dapat berkomunikasi sehingga bisa menyampaikan maksud dan tujuannya kepada lawan bicara.

Bahasa biasa digunakan sebagai alat komunikasi, salah satunya dalam dunia usaha. Pemilik usaha memanfaatkan media komunikasi ini, agar dapat berkomunikasi baik dengan semua konsumennya. Manusia kerap kali memberikan nama-nama atau labellabel yang unik sehingga kurang dimengerti, terhadap semua benda dan kejadian- 
kejadian yang ada di lingungan sekitarnya. Beraneka ragam benda atau kejadian tersebut, yang memengaruhi terciptanya nama-nama kelompok dari benda atau peristiwa, misalnya nama makanan, minuman, tumbuhan, buah, dan sebagainya (Chaer, 2013, hal. 44) . Penamaan adalah cara seseorang untuk memberikan suatu nama kepada benda. Pengertian tersebut selaras dengan Amalia (2017, hal. 19) yang menyatakan bahwa memberi atau

menuliskan bahasa dalam bentuk nama-nama pada benda.

Chaer (2013, hal. 44-52) menyatakan penamaan terdiri dari sembilan jenis yaitu, peniruan bunyi yang berasal terbentuk dari bunyi yang ditimbulkan dari benda tersebut, penyebutan bagian yang berasal dari ciri khas yang menonjol dari benda itu dan sudah diketahui umum, penyebutan sifat khas yang berasal dari ciri khas benda tersebut, penemu dan pembuat berasal dari nama penemunya, tempat asal berasal dari nama tempat asal benda tersebut, bahan berasal dari nama bahan pokok benda tersebut, keserupaan berasal dari makna yang dipersamakan atau diperbandingkan dengan makna leksikal kata itu, pemandekan berasal dari penggabungan unsur-unsur huruf awal atau suku kata dari beberapa yang digabungkan menjadi satu, dan penamaan baru berasal dari isitlah yang dibentuk untuk menggantikan kata atau istilah lama.

Menu merupakan salah satu kebijakan yang ditetapkan oleh restoran atau warung. Hal ini dapat diartikan bahwa menu merupakan suatu hidangan yang disiapkan untuk disajikan sebagai makanan, daftar makanan yang dipesan, dan daftar makanan yang akan dihidangkan (Komariah, 2010, hal. Vi/1). Menurut Gardjito (2016, hal. 99) menu adalah kombinasi hidangan dan urutannya dalam penyajian disusun untuk kurun waktu tertentu.

Penggunaan penamaan selalu digunakan oleh masyarakat, salah satunya pemilik usaha makanan bakso dan pisang goreng. Pengusaha atau pemilik rumah makan bakso dan pisang goreng menamai makanan tersebut pada daftar menu dengan nama-nama yang sesuai dengan maksud, harapan dan tujuan yang ingin dicapai. Beberapa tahun ini nama-nama makanan pada daftar menu makanan berkembang dan beraneka ragam.

Salah satu contoh nama makanan tersebut adalah bakso buah naga. Dasar penamaan bakso buah naga ini adalah bahan. Simbol atau kata adalah bakso buah naga, makna pada kata tersebut adalah bakso yang pentolnya terbuat dari tepung, daging, buah naga dan lain-lain kemudian dicetak bulat dan direbus hingga mengambang kemudian tiriskan. Bakso ini isiannya pentol buah naga, bawang goreng, seledri, dan kerupuk pangsit kemudian diberi kuah. Acuan pada kata dan makna tersebut abstrak yang tidak bisa diketahui gambarnya. Hal tersebut yang mendasari penamaan bakso ini dengan bakso buah naga.

Berdasarkan data di atas, penamaaan makanan berdasarkan bahan. Penamaan dengan bahan biasanya pada benda yang berbahan dasar tertentu. Bahan dasar hal tertentu itu akan menjadi nama dari benda tersebut. Ada beberapa nama makanan yang namanya diambil dari bahan pokok benda itu. Bakso buah naga makanan ini berbahan dasar pentol yang terbuat dari tepung, daging ayam, buah naga merah dan lain-lain. Dengan demikian, nama bakso buah naga ini adalah penggambaran jenis makanan 
dengan bakso daging yang dicampur dengan buah naga merah dan isian yang lainnya dalam sajian bakso tersebut.

Penamaan bahan tersebut pernah diungkap sebelumnya oleh Mulyadi. Penamaan bahan yang pernah diungkap oleh Mulyadi, sama dengan penelitian ini. Kesamaan dari penelitian ini yaitu penamaan tersebut berasal dari bahan utama dari menu makanan tersebut. Bakso buah naga muncul seiring dengan berkembangnya ide kreatif penjual untuk membuat olahan bakso yang berbeda dari lainnya. Selain itu, bakso tersebut juga memiliki kandungan gizi yang lebih sehat dan lengkap, karena selain berbahan dasar daging terdapat juga bahan yang berasal dari sayuran yaitu buah naga merah.

Perhatian pembeli pada penamaan menu makanan bisa dilihat dari penamaaan unik pada menu makanan. Ciri dari penamaan unik belum ditemukan. Mulyadi hanya menuliskan penamaan unik dalam bentuk denotatif yaitu mie rebus Jawa. Penelitian ini bakso buah naga merupakan penamaan unik dalam bentuk istilah. Buah naga tersebut merupakan buah dari salah satu jenis kaktus.

Nama-nama menu makanan yang unik seperti di atas akhir-akhir ini bermunculan. Terutamanya pada pulau Bali yang merupakan salah satu destinasi pariwisata di Indonesia yang paling ramai didatangi wisatawan asing maupun domestik. Seluruh pulau Bali mempunyai daya tarik alam yang memesona bagi para wistawan, utamanya pada kawasan Denpasar. Denpasar merupakan ibu kota Provinsi Bali, yang merupakan salah satu daerah paling banyak dikunjungi wisatawan asing maupun domestik. Banyaknya wisatawan yang berkunjung ke kota Denpasar menjadi daya tarik bagi masyarakat luar pulau Bali untuk mencari nafkah.

Masyarakat yang mencari nafkah di kota Denpasar banyak berwirausaha dengan berdagang, utamanya pedagang makanan. Pedagang yang berjualan tidak hanya dari luar pulau Bali, namun juga orang Bali. Para pedagang yang membuka usaha baik berupa cafe, warung makan, atau gerobak berjualan dengan lokasi yang berdekatan dan mempunyai usaha makanan yang hampir sama. Hal ini yang menjadi alasan para pedagang berusaha bersaing dengan sehat dengan cara menarik perhatian pembeli melalui tips dan trik yang khas. Salah satu tips wirausahawan yaitu dengan cara membuat daftar nama-nama menu makanan yang unik dan kreatif. Pembeli sekarang lebih suka membaca daftar menu makanan terlebih dahulu sebelum memesan makanan tersebut. Pemberian nama yang menarik membuat masyarakat merasa penasaran dan membeli makanan tersebut untuk mengetahui bagaimana rasa dari makanan, tanpa mengetahui arti nama makanan tersebut. Semakin unik nama dan bentuk suatu makanan, maka minat masyarakat untuk membelinya semakin besar. Penelitian ini dapat memberikan pengetahuan kepada masyarakat mengenai proses penamaan dari beberapa nama makanan kuliner unik yang difokuskan hanya pada bakso halal dan pisang goreng yang ada di Bali-Denpasar.

Terkait dengan penelitian ini, terdapat beberapa penelitian terdahulu yang hampir sama dengan penelitian ini, diantaranya : 1) Faisah (2014) yang berjudul "Nama Makanan dan Minuman Unik di Jember" mendeskripsikan tentang proses penamaan dan makna makanan unik dan minuman unik di Jember ditinjau secara semantik. Penelitian ini mengkaji jenis makanan berat dan lauk pauk, seperti nasi goreng selimut, 
sego kucing, sego tempong, nasi malaysia, dan lain-lain, serta minuman; 2) Mulyadi (2019) yang berjudul "Penamaan Tempat Usaha Dan Menu Kuliner Spesifik Mi Pada Fitur Goo-Food Dalam Aplikasi Go-Jek Area Padang Kajian Semantik" mendeskripsikan tentang penamaan dan makna tempat usaha dan menu kuliner spesifik mi; dan 3) Asrumi (2017) yang berjudul Mengungkap Di Balik Makna Nama-Nama Kuliner Dan Implikasinya Di Jember Jawa Timur (Tinjauan Sosiosemantik), mendeskripsikan tentang makna dan perubahan nama-nama kuliner, faktor-faktor yang melatarbelakangi, dampak penamaan terhadap animo konsumen, dan implikasinya dengan keterlibatan budaya panglaris berbisnis kuliner. Kajian-kajian tersebut memiliki kesamaan yaitu kajian semantik, namun terdapat perbedaan yakni pada objek yang diteliti berupa nama-nama menu makanan khusus bakso halal yang terdapat di media sosial seperti google, facebook, dan instagram wilayah Denpasar-Bali.

Berdasakan pemaparan diatas, peneliti tertarik untuk menelusuri lebih lanjut. Guna mengetahui bagaimana fenomena bahasa dalam nama-nama menu makanan yang difokuskan pada bakso halal di media sosial seperti google, facebook, dan instagram wilayah Denpasar-Bali. Penelitian ini bertujuan untuk mendeskripsikan bentuk penamaan nama-nama menu makanan khusus bakso halal dan pisang goreng. Penelitian mengenai nama-nama menu makanan ini dapat menambah wawasan dan pengetahuan dalam pembelajaran bahasa Indonesia, khususnya mahasiswa bahasa Indonesia yang akan menjadi pendidik. Calon pendidik harus mampu mengetahui perkembangan bahasa yang dinamis, sehingga menghasilkan kata baru. Berdasarkan penjabaran diatas, maka penelitian ini berjudul "Penamaan Menu Makanan Di Bali".

\section{METODE PENELITIAN}

Penelitian ini merupakan penelitian deskriptif kualitatif yang menganalisis dan memaparkan hasil penelitian dengan menggunakan kata atau kalimat. Data dalam penelitian ini yaitu daftar menu atau banner makanan yang ada di cafe, warung atau gerobak. Sumber data dalam penelitian ini adalah daftar nama-nama menu makanan khusus bakso halal di sosial media seperti google, facebook, dan instagram. Tahap analisis data tebagi menjadi tiga yaitu : 1) tahap reduksi data, 2) tahap penyajian data, dan 3) tahap verification.

Pertama tahap reduksi data. Mereduksi data berarti merangkum, memilih hal-hal yang pokok, memfokuskan kepada hal-hal yang penting. Peneliti menggunakan teknik pengumpulan data yaitu dengan dokumentasi, berupa foto atau screenshoot daftar menu makanan khusus bakso halal dan pisang goreng. Data penelitian ini diperoleh dengan menggunakan metode simak bebas libat cakap. Kegiatan menyimak ini berupa penyimakan bahasa tulis yang terdapat dalam menu makanan, banner, atau gerobak, tanpa ikut serta dalam tuturan untuk memperoleh data tersebut. Data tersebut kemudian disadap. Teknik sadap disebut sebagai teknik dasar dalam metode simak karena pada hakikatnya penyimakan wujudnya dengan penyadapan. Peneliti melakukan penyadapan penggunaan bahasa secara tertulis yang berupa daftar nama-nama menu makanan khusus bakso halal dan pisang goreng tersebut. Selanjutnya teknik catat yang dilakukan jika menerapkan metode simak. Selain dicatat, agar data valid dan sahih perlu dilakukan 
rekam visual berupa screenshoot atau penyimpanan foto pada sumber data. Peneliti juga menggunakan teknik Pilah Unsur Penentu (PUP), karena dalam proses reduksi data, peneliti harus jeli dan mampu memilah-milah data yang sesuai dengan jenis penamaan sebagai data penelitian.

Kedua tahap penyajiaan data. Pada tahap kedua peneliti akan memaparkan data dari hasil reduksi data. Data yang telah direduksi sudah sesuai dengan pembagian jenis penamaan menu makanan khusus bakso halal dan pisang goreng. Data yang sudah direduksi kemudian dianalisis. Peneliti mendeskripsikan hasil analisis dengan menggunakan bahasa yang mudah dipahami oleh pembaca. Peneliti menganalisis data dengan menggunakan metode padan. Menurut Sudaryanto (2015, hal. 15), metode padan adalah metode analisis yang alat penentunya di luar, terlepas, dan tidak menjadi bagian dari bahasa yang bersangkutan. Metode yang digunakan ada dua yaitu referensial dan otografis. Metode referensial alat penentunya berupa kenyataan yang sesuai dengan bahasa atau referen bahasa. Metode otografis alat penentunya berupa perekam visual, yaitu foto tulisan pada menu makanan. Peneliti melakukan pengujian kesahihan data dengan meningkatkan ketekunan dan triangulasi. Meningkatkan ketekunan berarti melakukan pengamatan secara lebih cermat dan berkesinambungan. Triangulasi berarti mengecek kembali data yang telah ditemukan dengan memanfaatkan pengamat lainnya untuk mengurangi kemelencengan dalam pengumpulan data. Penelitian ini memanfaatkan pengamat lain yaitu Diana Maulida Rahman M.Li untuk mengecek data yang telah ditemukan oleh peneliti.

Ketiga tahap verification. Peneliti memeriksa berulang kali data yang telah dianalisis dicek kembali. Data dicek sampai benar-benar menghasilkan data yang valid.

\section{PEMBAHASAN}

\section{Bentuk Proses Penamaan Menu Makanan Khusus Bakso di Denpasar-Bali}

Di bawah ini dipaparkan proses penamaan nama-nama menu makanan ditinjau secara semantik. Proses penamaan tersebut antara lain peniruan bunyi, penyebutan bagian, penyebutan sifat khas,penemu atau pembuat, tempat asal, bahan, keserupaan, pemendekan, dan penamaan baru. Berikut penjelasan data yang telah ditemukan.

a. Peniruan Bunyi

Pada penelitian ini ditemukan satu nama menu makanan yang penamaannya berdasarkan peniruan bunyi. Berikut datanya.

1) Pisang Goreng Kriuk

Dasar penamaan data (1) ini adalah peniruan bunyi. Simbol atau kata adalah pisang goreng kriuk, makna pada kata tersebut adalah buah pisang yang sudah dikupas kemudian dibaluri tepung, gula dan lain-lain kemudian di masukkan ke dalam minyak hingga berwarna kuning keemasan kemudian diangkat dan tiriskanketika dimakan. Acuan pada kata dan makna tersebut abstrak yang tidak bisa diketahui gambarnya. Pisang goreng yang ketika dimakan menimbulkan suara kriuk yang menyebabkan 
Pisang goreng ini dinamakan Pisang Goreng Kriuk. Hal tersebut yang mendasari penamaan ini dengan pisang goreng kriuk.

Berdasarkan data (1) di atas, Penamaan benda berdasarkan bunyi pada menu makanan diidentifikasi bunyi crunchy. Crunchy dalam bahasa Indonesia berarti kriuk. Alasan tersebut dikarenakan bunyi yang keluar ketika orang memakan pisang goreng tersebut kriuk, kriuk. Bunyi crunchy atau kriuk merupakan salah satu jenis onomatope yang diungkap oleh Abdul Chaer. Nama pisang goreng kriuk tersebut dibentuk berdasarkan bunyi yang ditimbulkan oleh pisang goreng ketika dimakan, terdengar bunyi kriuk,kriuk.

Dilihat dari fungsinya, fungsi penamaan berdasarkan bunyi pada makanan pisang goreng. Fungsinya yaitu sebagai nama makanan yang menghasilkan tiruan bunyi dari makanan tersebut ketika dimakan. Fungsi peniruan bunyi pada pisang goreng kriuk ini dapat memberikan informasi kepada pembeli, bahwa pisang goreng tersebut renyah dan crunchy ketika dimakan. Fungsi tersebut belum pernah diungkap sebelumnya oleh artikel yang dijadikan pembanding oleh peneliti.

Perhatian pembeli pada penamaan menu makanan bisa dilihat dari penamaaan unik pada menu makanan. Ciri dari penamaan unik belum ditemukan. Mulyadi hanya menuliskan penamaan unik dalam bentuk kias Mie Padeh Huuhaa : Hihihihi original. Penelitian ini Pisang Goreng Kriuk merupakan makna yang non-referensial. Makna non-referensial kata Kriuk pada makanan yang terdapat dalam penelitian ini ada, tetapi tidak memiliki referen.

\section{b. Penyebutan Bagian}

Pada penelitian ini ditemukan satu nama menu makanan yang penamaannya berdasarkan penyebutan bagian. Berikut datanya.

2) Bakso Tulang

Dasar penamaan data (2) ini adalah penyebutan bagaian. Simbol atau kata adalah bakso tulang, makna pada kata tersebut adalah sajian bakso yang didalamnya terdapat pentol, tulang sapi, mie seledri, bawang goreng, dan kuah. Acuan pada kata dan makna tersebut abstrak yang tidak bisa diketahui gambarnya. Bakso tulang merupakan penyebutan bagian dari menu bakso, tulang dalam menu ini hanya satu bagian diantara keseluruhan isi penyajian. Hal tersebut yang mendasari penamaan ini dengan bakso tulang.

Berdasarkan data (2) di atas, penamaan berdasarkan penyebutan bagian merupakan pars prototo yaitu gaya bahasa yang menyebutkan bagian dari suatu benda, padahal yang dimaksud keseluruhannya. Penamaan ini didasarkan atas ciri khas yang menonjol dari bakso tersebut dan sudah diketahui oleh masyarakat umum. Bakso tulang bukan bakso yang hanya berisi tulang sapi, melainkan beberapa isian yang lainnya juga, seperti, pentol, mie, seledri, bawang goreng, dan kuah. Masyarakat umum sudah mengetahui bahwa nama bakso tulang merupakan bakso yang isiannya paling menonjol dalam mangkok yaitu tulang sapi.

Penyebutan bagian tersebut belum pernah diungkap sebelumnya. Penyebutan bagian dalam penelitian ini yaitu mengambil nama dari salah satu sajian yang 
mempunyai ciri khas dan paling menonjol dari makanan tersebut serta masyarakat sudah mengetahuinya. Bakso tulang yang paling menonjol dalam sajian bakso ini yaitu tulang sapi, tidak hanya tulang sapi saja isiannya tetapi ada pentol dan mie.

\section{c. Penyebutan Sifat Khas}

Pada penelitian ini ditemukan satu nama-nama menu makanan yang penamaannya berdasarkan sifat khas. Berikut datanya.

3) Bakso penyet .

Dasar penamaan (3) ini adalah sifat khas.

Simbol atau kata adalah bakso penyet. Makna pada kata tersebut adalah pentol yang dipenyet, diberi sambal dan hiasan timun, tomat dan selada hijau ditempatkan diatas piring, kemudian diberi kuah. Acuan pada kata dan makna tersebut abstrak yang tidak bisa diketahui gambarnya. Bakso tersebut diberi nama bakso penyet karena bakso disajikan dalam keadaan penyet. Hal tersebut yang mendasari penamaan bakso ini dengan bakso penyet.

Berdasarkan data (3) di atas, penamaan berdasarkan sifat khas pada menu makanan bakso penyet yaitu, penyet dalam KBBI V (Daring) merupakan bentuk tidak baku dari kata penyek yang berarti pipih karena terhimpit. Ciri khas dari bakso ini adalah pentol yang dipipihkan sehingga bentuk pentol tersebut tidak utuh bulat tetapi berubah bentuk menjadi penyet. Penamaan sifat khas ini didasari oleh sifat yang amat menonjol dari menu makanan tersebut, sehingga akhirnya kata sifat itulah yang menjadi nama bendanya, yaitu bakso penyet.

Penamaan sifat khas berdasarkan sifat yang amat menonjol dari bentuk makanan tersebut pernah diungkap sebelumnya oleh Faisah. Sifat khas yang pernah diungkap oleh Faisah dan penelitian ini sama. Kesamaan dari penelitian ini yaitu bentuk dari menu makanan tersebut berubah dan yang menjadikan makanan tersebut memiliki ciri khas tersendiri. Penelitian Faisah memaparkan ayam remuk sebagai ciri khasnya, dalam penelitian ini bakso penyet yang menjadi ciri khasnya. Penamaan ini harus memperhatikan kata sifat yang menonjol dari makanan tersebut.

Perhatian pembeli pada penamaan menu makanan bisa dilihat dari penamaaan unik pada menu makanan. Ciri dari penamaan unik belum ditemukan. Faisah hanya menuliskan penamaan unik dalam bentuk leksikal yaitu ayam remuk. Penelitian ini Bakso Penyet juga merupakan makna leksikal. Makna leksikal Bakso menurut KBBI V (daring) adalah makanan yang terbuat dari daging, udang, ikan yang dicincang dan dilumatkan bersama tepung kanji dan putih telur, biasanya dibentuk bulat-bulat. Penyet menurut KBBI V (Daring) berasal dari bentuk baku penyek yang berarti pipih karena terinjak, terhimpit, dan sebagainya.

d. Penemu atau pembuat

Pada penelitian ini ditemukan satu nama-nama menu makanan yang penamaannya berdasarkan penemu atau pembuat. Berikut datanya.

4) Bakso Mas Doel. 
Dasar penamaan (4) ini adalah penemu atau pembuat. Simbol atau kata adalah mas Doel, makna pada kata tersebut adalah bakso yang isiannya berupa pentol, tahu, mie, pangsit basah, pangsit kering dan kuah. Acuan pada kata dan makna tersebut abstrak yang tidak bisa diketahui gambarnya. Bakso tersebut diberi nama Bakso Mas Doel karena pak Doel selaku pembuat dan pemilik usaha tersebut. Hal tersebut yang mendasari penamaan bakso ini dengan Bakso Mas Doel.

Berdasarkan data (4) di atas, penamaaan makanan berdasarkan nama penemu atau pembuat dapat digunakan dengan beberapa syarat. Syarat-syarat tersebut antara lain, harus sesuai dengan nama orang yang menemukan atau membuat menu makanan, dapat menggunakan nama keluarga yang dianggap unik, dan nama tokoh-tokoh yang diidolakannya. Syarat tersebut harus diterapkan, kalau tidak memenuhi syarat tersebut, maka penamaan berdasarkan penemu tidak akan menarik perhatian pembeli. Nama Doel dalam bakso ini merupakan orang yang membuat dan pemiliki usaha, dan secara kebetulan nama Doel merupakan salah satu nama tokoh yang terdapat dalam sinetron SI Doel Anak Sekolahan.

Penamaan penemu atau pembuat tersebut pernah diungkap sebelumnya oleh Mulyadi. Penemu atau pembuat yang pernah diungkap oleh Mulyadi dan penelitian ini sama. Kesamaan dari penelitian ini yaitu penamaan tersebut berasal dari penemu atau pemilik usaha tersebut. Tetapi secara kebetulan nama dari penelitian ini sama salah satu tokoh yang terdapat dalam sinetron di televisi. Penamaan dengan menggunakan nama penemu atau pembuat ini memberikan informasi bahwa bakso tersebut merupakan usaha milik nama orang yang sudah tertera di salah satu menu makanan baik di dalam daftar menu makanan ataupun banner.

Perhatian pembeli pada penamaan menu makanan bisa dilihat dari penamaaan unik pada menu makanan. Ciri dari penamaan unik belum ditemukan. Faisah dkk hanya menuliskan penamaan unik dalam bentuk asosiatif yaitu gurami dewa-dewi. Penelitian ini Bakso Mas Doel merupakan penamaan unik dalam bentuk referensial. Bakso mas Doel tersebut mempunyai makna yang berhubungan langsung dengan kenyataannya.

Penamaan dengan penemu atau pembuat yang tidak unik, bisa terjadi karena pemilik usaha menamai dengan nama yang kurang menarik, seperti, bakso Muri dan bakso cak Man. Bakso tersebut kurang menarik, karena nama yang dipakai biasa-biasa saja. Nama bakso tersebut bisa diganti dengan menggunakan kata tambahan yang lebih unik atau diganti dengan menggunakan nama tokoh idola dari penemu menu makanan tersebut. Bakso tersebut dapat ditambahi dengan kata bakso rekor Muri dan bakso cak SpiderMan.

\section{e. Tempat Asal}

Pada penelitian ini ditemukan satu nama-nama menu makanan yang penamaannya berdasarkan tempat asal. Berikut datanya.

5) Bakso Solo.

Dasar penamaan (5) ini adalah tempat asal.

Simbol atau kata adalah bakso Solo, makna pada kata tersebut adalah bakso yang isiannya pentol, bawang goreng dan seledri kemudian diberi kuah. Resep bakso tersebut 
berasal dari Solo. Acuan pada kata dan makna tersebut abstrak yang tidak bisa diketahui gambarnya. Hal tersebut yang mendasari penamaan bakso ini dengan bakso Solo.

Berdasarkan data (5) di atas, penamaaan makanan berdasarkan tempat asal. Penamaan berdasarkan tempat asal merupakan penamaan suatu makanan dengan menempelkan kata tempat asal makanan tersebut. Bakso Solo dapat ditelusuri makanan tersebut berasal dari tempat bernama Solo yang terdapat di Jawa Tengah. Bakso Solo ini yang berasal dari kota Solo yaitu resep yang digunakan untuk membuat makanan bakso.

Penamaan tempat asal tersebut pernah diungkap sebelumnya oleh Faisah. Tempat asal yang pernah diungkap oleh Faisah dan penelitian ini hampir sama. Kesamaan dari penelitian ini yaitu sama-sama menggunakan resep dari daerah asalnya yang digunakan untuk membuat olahan makanan tersebut. Terdapat sedikit perbedaan, jika dalam penelitian Faisah terdapat tambahan kata ngetop pada nama makanannya yaitu bebek ngetop Surabaya, tetapi pada penelitian ini tidak terdapat kata tambahan apapun.

Perhatian pembeli pada penamaan menu makanan bisa dilihat dari penamaaan unik pada menu makanan. Ciri dari penamaan unik belum ditemukan. Faisah dkk hanya menuliskan penamaan unik dalam bentuk leksikal yaitu mie Jawa. Penelitian ini bakso Solo juga merupakan penamaan unik dalam bentuk leksikal. Bakso Solo tersebut mempunyai makna yangdapat ditelusuri di kamus. Bakso menurut KBBI V (Daring) berarti makanan yanng terbuat dari daging, udang, ikan yang dicincang dan dilumatkan bersama tepung kanji dan putih telur, biasanya dibentuk bulat-bulat. Solo menurut KBBI V (Daring) berarti Surakarta. Jadi bakso Solo diartikan sebagai menu makanan bakso dengan resep olahan yang khas dari daerah di Surakarta yaitu Solo dan berbeda dengan olahan bakso dari daerah lain.

\section{f. Bahan}

Pada penelitian ini ditemukan tiga nama-nama menu makanan yang penamaannya berdasarkan keserupaan. Nama tersebut adalah bakso ayam lamtoro, bakso mozarela, dan bakso ayam sawi hijau. Berikut datanya.

6) Bakso ayam lamtoro (1 Bh)

Dasar penamaan (6) ini adalah bahan. Simbol atau kata adalah bakso ayam lamtoro, makna pada kata tersebut adalah bakso yang pentolnya terbuat dari tepung, daging, biji lamtoro dan lain-lain kemudian dicetak bulat dan direbus hingga mengambang kemudian tiriskan. Bakso ini isiannya pentol ayam lamtoro, bawang goreng, seledri, dan kerupuk pangsit kemudian diberi kuah. Acuan pada kata dan makna tersebut abstrak yang tidak bisa diketahui gambarnya. Hal tersebut yang mendasari penamaan bakso ini dengan bakso ayam lamtoro.

Berdasarkan data (6) di atas, penamaaan makanan berdasarkan bahan. Penamaan dengan bahan biasanya pada benda yang berbahan dasar tertentu. Bahan dasar hal tertentu itu akan menjadi nama dari benda tersebut. Ada beberapa nama makanan yang namanya diambil dari bahan pokok benda itu. Bakso ayam lamtoro makanan ini berbahan dasar pentol yang terbuat dari tepung, daging ayam, biji lamtoro dan lain-lain. Dengan demikian, nama bakso ayam lamtoro ini adalah penggambaran jenis makanan 
dengan pentol yang terdapat biji lamtoro dan isian yang lainnya dalam sajian bakso tersebut.

Penamaan bahan tersebut pernah diungkap sebelumnya oleh Mulyadi dan Faisah. Penamaan bahan yang pernah diungkap oleh Mulyadi dan Faisah, sama dengan penelitian ini. Kesamaan dari penelitian ini yaitu penamaan tersebut berasal dari bahan utama dari menu makanan tersebut. Bakso ayam lamtoro muncul seiring dengan berkembangnya ide kreatif penjual untuk membuat olahan bakso yang berbeda dari lainnya. Selain itu, bakso tersebut juga memiliki kandungan gizi yang lebih sehat dan lengkap, karena selain berbahan dasar daging terdapat juga bahan yang berasal dari sayuran yaitu biji lamtoro.

Perhatian pembeli pada penamaan menu makanan bisa dilihat dari penamaaan unik pada menu makanan. Ciri dari penamaan unik belum ditemukan. Mulyadi, Faisah dkk hanya menuliskan penamaan unik dalam bentuk leksikal dan denotatif yaitu bakso serabutan dan mie ayam. Penelitian ini bakso ayam lamtoro merupakan penamaan unik dalam bentuk leksikal. Bakso ayam lamtoro tersebut mempunyai makna yang sesuai dengan kamus. Bakso menurut KBBI V (Daring) berarti makanan yanng terbuat dari daging, udang, ikan yang dicincang dan dilumatkan bersama tepung kanji dan putih telur, biasanya dibentuk bulat-bulat. Lamtoro menurut KBBI V (Daring) berarti biji lamtoro. Jadi bakso ayam lamtoro merupakan olahan makanan yang terbuat dari daging, dilumatkan bersama kanji, putih telur, biji lamtoro sebagai bahan campuran dan bahanbahan yang lainnya.

\section{7) Bakso Mozarela (2 Bh)}

Dasar penamaan (7) ini adalah bahan. Simbol atau kata adalah bakso mozarela, makna pada kata tersebut adalah bakso yang pentolnya terbuat dari tepung, daging dan diberi isian keju mozarela ditengah pentol, dicetak bulat dan direbus hingga mengambang kemudian tiriskan. Bakso ini isiannya pentol keju mozarela, pangsit basah, tahu coklat, mie, sayur, bawang goreng dan seledri kemudian diberi kuah. Acuan pada kata dan makna tersebut abstrak yang tidak bisa diketahui gambarnya. Hal tersebut yang mendasari penamaan bakso ini dengan bakso mozarela.

Berdasarkan data (7) di atas, penamaaan makanan berdasarkan bahan. Penamaan dengan bahan biasanya pada benda yang berbahan dasar tertentu. Bahan dasar hal tertentu itu akan menjadi nama dari benda tersebut. Ada beberapa nama makanan yang namanya diambil dari bahan pokok benda itu. Bakso mozarela makanan ini berbahan dasar pentol yang terbuat dari tepung, daging ayam, bahan-bahan lainnya dan diisi bagian tengahnya dengan keju mozarela. Dengan demikian, nama bakso mozarela ini adalah penggambaran jenis makanan dengan pentol ditengahnya diisi dengan keju mozarela dan pelengkap isian yang lainnya dalam sajian bakso tersebut.

Penamaan bahan tersebut pernah diungkap sebelumnya oleh Mulyadi. Penamaan bahan yang pernah diungkap oleh Mulyadi, sama dengan penelitian ini. Kesamaan dari penelitian ini yaitu penamaan tersebut berasal dari bahan utama dari menu makanan tersebut. Bakso mozarela muncul seiring dengan berkembangnya ide kreatif penjual 
untuk membuat olahan bakso dimana tengah-tengah bakso tersebut terdapat isian yang berbeda dari bagian luarnya.

Perhatian pembeli pada penamaan menu makanan bisa dilihat dari penamaaan unik pada menu makanan. Ciri dari penamaan unik belum ditemukan. Mulyadi hanya menuliskan penamaan unik dalam bentuk denotatif yaitu mie goreng Jawa. Penelitian ini bakso mozarela merupakan penamaan unik dalam bentuk leksikal. Bakso mozarela tersebut mempunyai makna yang sesuai dengan kamus. Bakso menurut KBBI V (Daring) berarti makanan yanng terbuat dari daging, udang, ikan yang dicincang dan dilumatkan bersama tepung kanji dan putih telur, biasanya dibentuk bulat-bulat. Mozarela merupakan salah satu jenis keju. Keju menurut KBBI V (Daring) berarti bahan makanan yang dibuat dari sari air susu melalui proses peragian yang keraskan (dikentalkan). Jadi bakso mozarela merupakan olahan makanan yang terbuat dari daging, dilumatkan bersama kanji, putih telur, dan bahan-bahan lainnya, kemudian ditengahnya diisi dengan potongan keju mozarela.

\section{8) Bakso Ayam Sawi Hijau (3 Bh)}

Dasar penamaan (8) ini adalah bahan Simbol atau kata adalah Bakso Ayam Sawi Hijau, makna pada kata tersebut adalah bakso yang pentolnya terbuat dari tepung, daging, sawi hijau dan lain-lain kemudian dicetak bulat dan direbus hingga mengambang kemudian tiriskan. bakso ini isiannya pentol sawi hijau, bawang goreng, seledri, dan kerupuk pangsit kemudian diberi kuah. Acuan pada kata dan makna tersebut abstrak yang tidak bisa diketahui gambarnya. Hal tersebut yang mendasari penamaan bakso ini dengan Bakso Ayam Sawi Hijau.

Berdasarkan data (8) di atas, penamaaan makanan berdasarkan bahan. Penamaan dengan bahan biasanya pada benda yang berbahan dasar tertentu. Bahan dasar hal tertentu itu akan menjadi nama dari benda tersebut. Ada beberapa nama makanan yang namanya diambil dari bahan pokok benda itu. Bakso Ayam Sawi Hijau makanan ini berbahan dasar pentol yang terbuat dari tepung, daging ayam, sawi hijau dan lain-lain. Dengan demikian, nama bakso ayam sawi hijau ini adalah penggambaran jenis makanan dengan bakso daging yang dicampur dengan sayur sawi hijau dan isian yang lainnya dalam sajian bakso tersebut.

Penamaan bahan tersebut pernah diungkap sebelumnya oleh Mulyadi. Penamaan bahan yang pernah diungkap oleh Mulyadi, sama dengan penelitian ini. Kesamaan dari penelitian ini yaitu penamaan tersebut berasal dari bahan utama dari menu makanan tersebut. Bakso ayam sawi hijau muncul seiring dengan berkembangnya ide kreatif penjual untuk membuat olahan bakso yang berbeda dari lainnya. Selain itu, bakso tersebut juga memiliki kandungan gizi yang lebih sehat dan lengkap, karena selain berbahan dasar daging terdapat juga bahan yang berasal dari sayuran yaitu sawi hijau.

Perhatian pembeli pada penamaan menu makanan bisa dilihat dari penamaaan unik pada menu makanan. Ciri dari penamaan unik belum ditemukan. Mulyadi hanya menuliskan penamaan unik dalam bentuk denotatif yaitu mie rebus Jawa. Penelitian ini bakso ayam sawi hijau merupakan penamaan unik dalam bentuk leksikal. Bakso ayam sawi hijau tersebut mempunyai makna yang sesuai dengan kamus. Bakso menurut 
KBBI V (Daring) berarti makanan yanng terbuat dari daging, udang, ikan yang dicincang dan dilumatkan bersama tepung kanji dan putih telur, biasanya dibentuk bulat-bulat. Sawi menurut KBBI V (Daring) berarti sayuran, berdaun melebar, pinggir daun bercuping gelombang, berwarna hijau pucat, dengan tulang dan tangkai melebar. Jadi bakso ayam lamtoro merupakan olahan makanan yang terbuat dari daging, dilumatkan bersama kanji, putih telur, sawi hijau sebagai bahan campuran dan bahanbahan yang lainnya.

\section{g. Keserupaan}

Pada penelitian ini ditemukan dua nama-nama menu makanan yang penamaannya berdasarkan keserupaan. Nama tersebut adalah bakso bomok dan bakso cinta. Berikut datanya.

9) Bakso Bomok (1 Ks)

Dasar penamaan (9) ini adalah keserupaan.

Simbol atau kata adalah bakso bomok, makna pada kata tersebut adalah bakso bomok ini terbuat dari bahan dasar adonan daging ayam yang telah dibumbui dan berbentuk bulat mekar besar. Acuan pada kata dan makna tersebut abstrak yang tidak bisa diketahui gambarnya. Hal tersebut yang mendasari penamaan bakso ini dengan bakso bomok.

Berdasarkan data (9) di atas, penamaaan makanan berdasarkan keserupaan. Penamaan dengan keserupaan ini merupakan kata yang digunakan dalam suatu ujaran yang maknanya dipersamakan atau diperbandingkan dengan makna leksikal dari kata itu. Bakso tersebut berasal dari kata bom, namun diberi imbuhan ok karena sesuai dengan dialek bahasa orang Blitar yang menambahkan suku kata ok setiap berbicara dan diletakkan akhir kata.

Penamaan bahan tersebut pernah diungkap sebelumnya oleh Faisah. Penamaan keserupaan yang pernah diungkap oleh Faisah, sama dengan penelitian ini. Kesamaan dari penelitian ini yaitu persamaan makanan tersebut dengan makna leksikal. Serta penyamaannya dalam hal bentuk makanan tersebut. Penelitian Faisah dengan menu makanan keserupaan yaitu nasi goreng selimut. Penelitian ini menu makanan keserupaan yaitu bakso bomok. Bom menurut KBBI V Daring yaitu senjata yang bentuknya seperti peluru besar yang berisi bahan peledak yang menimbulkan kerusakan besar. Kesamaan dari bentuk bulat mekar besar dengan bom yang berbentuk bola ini yang menyebabkan bakso bomok mempunyai keserupaan dengan bom.

Perhatian pembeli pada penamaan menu makanan bisa dilihat dari penamaaan unik pada menu makanan. Ciri dari penamaan unik belum ditemukan. Faisah dkk hanya menuliskan penamaan unik dalam bentuk idiom yaitu mie setan. Penelitian ini bakso bomok merupakan penamaan unik dalam bentuk asosiatif. Bomok tersebut berasal dari kata bom dan ok. Bakso bomok diasosiasikan dengan bentuk bom yang sesuai dengan presepsi masyarakat yaitu berbentuk besar.

10) Bakso Cinta (2 Ks)

Dasar penamaan (10) ini adalah keserupaan. 
Simbol atau kata adalah bakso cinta, makna pada kata tersebut adalah bakso cinta ini terbuat dari bahan dasar adonan daging ayam yang telah dibumbui dan berbentuk love atau hati. Bakso cinta ini diserupakan dengan bentuk love yang identik dengan orang jatuh cinta. Acuan pada kata dan makna tersebut abstrak yang tidak bisa diketahui gambarnya. Hal tersebut yang mendasari penamaan bakso ini dengan bakso cinta.

Berdasarkan data (10) di atas, penamaaan makanan berdasarkan keserupaan. Penamaan berdasarkan keserupaan ini merupakan kata yang digunakan dalam suatu ujaran yang maknanya dipersamakan atau diperbandingkan dengan makna leksikal dari kata itu. Bakso cinta tersebut dipersamakan dengan makna leksikalnya. Bakso menurut KBBI V (Daring) berarti makanan yanng terbuat dari daging, udang, ikan yang dicincang dan dilumatkan bersama tepung kanji dan putih telur, biasanya dibentuk bulat-bulat. Cinta menurut KBBI V (Daring) berarti suka sekali, sayang benar, kasih sekali, rindu. Jadi bakso cinta merupakan bakso yang bentuknya mewakili simbol orang yang sedang jatuh cinta yaitu berbentuk love.

Penamaan keserupaan tersebut belum pernah diungkap sebelumnya oleh Mulyadi. Penamaan keserupaan yang pernah diungkap oleh Mulyadi hanya mengasosiasikan nama menu makananan tersebut dengan cita rasa pedas. Sedangkan dalam penelitian ini, peneliti mengasosiakan bentuk menu makanan bakso tersebut dengan simbol orang yang sedang jatuh cinta.

Perhatian pembeli pada penamaan menu makanan bisa dilihat dari penamaaan unik pada menu makanan. Ciri dari penamaan unik belum ditemukan. Mulyadi hanya menuliskan penamaan unik dalam bentuk istilah level sebagai penanda tingkat kepedasan. Penelitian ini bakso cinta merupakan penamaan unik dalam bentuk asosiatif. Bakso tersebut diasosiasikan dengan simbol seseorang yang sedang jatuh cinta.

h. Pemendekan

Pada penelitian ini ditemukan satu nama-nama menu makanan yang penamaannya berdasarkan pemendekan. Berikut datanya.

11) Bakso BBQ.

Dasar penamaan (11) ini adalah pemendekan. Simbol atau kata adalah bakso BBQ, makna pada kata tersebut adalah bakso BBQ ini terbuat dari bahan dasar adonan daging sapi/ayam yang telah dibumbui, dicetak bulat, direbus hingga mengambang, lalu tiriskan, setelah dingin pentol ditusuk, kemudian dipanggang. Bakso BBQ ini merupakan singkatan dari bakso barbeque. Acuan pada kata dan makna tersebut abstrak yang tidak bisa diketahui gambarnya. Hal tersebut yang mendasari penamaan bakso ini dengan bakso barbeque.

Berdasarkan data (11) di atas, penamaaan makanan berdasarkan pemendekan. Penamaan dengan pemendekan terbentuk sebagai hasil penggabungan atau kata-kata yang terbentuk sebagai hasil penyingkatan dari suatu nama benda. Penamaan dengan pemendekan mampu menarik perhatian pembeli. Penjual dapat membuat singkatan yang menarik dengan memperhatikan beberapa hal. Beberapa hal diantaranya singkatan dapat diambil dari satu kata huruf awal dan suku kata awal, tengah, ataupun akhir. Singkatan 
atau akronim harus dibuat dengan hasil penggabungan yang berupa kata menarik, sehingga pembeli merasa penasaran dan mau membelinya.

Pemendekan tersebut pernah diungkap sebelumnya oleh Faisah. Pemendekan yang pernah diungkap oleh Faisah, tidak sama dengan penelitian ini. perbedaannya terletak pada cara penyingkatan nama menu tersebut. Jika penelitian Faisah menunya yaitu Jerman yang merupakan kepanjangan dari jeruk manis. Penelitian tersebut menggunakan penyingkatan berupa suku kata awal pada dua kata tersebut. Dalam penelitian ini menunya yaitu bakso BBQ yang merupakan kepanjangan dari bakso barbeque. Penelitian ini menggunakan penyingkatan kata yang kedua berupa pengambilan satu huruf diawal suku kata pertama, satu huruf diawal suku kata kedua, dan satu huruf diawal suku kata ketiga.

Perhatian pembeli pada penamaan menu makanan bisa dilihat dari penamaaan unik pada menu makanan. Ciri dari penamaan unik belum ditemukan. Faisah hanya menuliskan penamaan unik dalam bentuk leksikal yaitu kubisu singkatan dari Kukubima dan susu. Penelitian ini bakso BBQ merupakan penamaan unik dalam bentuk leksikal. Barbeque merupakan kata yang berasal dari bahasa inggris dan jika diartikan dalam bahasa Indonesia yaitu panggang. Bakso menurut KBBI V (Daring) berarti makanan yanng terbuat dari daging, udang, ikan yang dicincang dan dilumatkan bersama tepung kanji dan putih telur, biasanya dibentuk bulat-bulat. Panggang menurut KBBI V (Daring) berarti dipanaskan (dimasak) di atas bara api. Jadi bakso BBQ merupakan olahan makanan yang terbuat dari daging, dilumatkan bersama kanji, putih telur, dan bahan-bahan yang lainnya setelah dibentuk bulat, kemudian dimasak hingga mengambang setelah itu ditiriskan, yang terakhir bakso tersebut ditusuk dan dipanggang.

\section{i. Penamaan Baru}

Pada penelitian ini ditemukan satu nama-nama menu makanan yang penamaannya berdasarkan peniruan bunyi. Nama tersebut adalah Bakso Super Pedas. Berikut datanya.

12) Bakso Super Pedas

Dasar penamaan data (12) di atas ini adalah penamaan baru. Simbol atau kata adalah Bakso Super Pedas, makna pada kata tersebut adalah ini terbuat dari bahan dasar adonan daging ayam yang telah dibumbui dicampur dengan olahan cabai, dicetak bulat, direbus hingga mengambang, lalu tiriskan. Kemudian disajikan dengan pentol super pedas, mie, pangsit goreng, seledri, bawang goreng, dan kuah. Acuan pada kata dan makna tersebut abstrak yang tidak bisa diketahui gambarnya. Penamaan bakso super pedas ini merupakan nama makanan atau sebutan baru yang jauh lebih halus, tepat dan rasional, dibandingkan penamaan menu bakso mercon yang kurang tepat, dan tidak rasional. Hal tersebut yang mendasari penamaan ini dengan bakso super pedas.

Berdasarkan data (12) di atas, penamaaan makanan berdasarkan penamaan baru. Penamaan baru ini terbentuk untuk menggantikan kata atau istilah lama yang sudah ada. Kata-kata atau istilah lama yang sudah ada itu perlu diganti dengan kata-kata baru, karena dianggap kurang tepat, tidak rasional, kurang halus, atau kurang ilmiah. 
Misalnya, bakso mercon perlu diganti dengan menggunakan nama bakso super pedas. Proses pergantian nama menu makanan akan terus berlangsung dan berkembang sesuai dengan pandangan dan norma budaya yang berlaku di masyarakat.

Penamaan baru tersebut pernah diungkap sebelumnya oleh Faisah. Penamaan baru yang pernah diungkap oleh Faisah, tidak sama dengan penelitian ini. Perbedaannya terletak pada penamaan menu makanan dalam penelitian Faisah yang menggunakan kata kurang tepat, yaitu mie galau. Dalam penelitian ini merubah kata mercon dalam menu bakso yang kurang tepat dan tidak rasional, menjadi nama menu makanan yang tepat, rasional, dan halus. Bakso mercon yang sudah lama terkenal di masyarakat dapat diganti dengan nama menu bakso super pedas.

Perhatian pembeli pada penamaan menu makanan bisa dilihat dari penamaaan unik pada menu makanan. Ciri dari penamaan unik belum ditemukan. Faisah hanya menuliskan penamaan unik dalam bentuk asosiatif yaitu es tuyul. Penelitian ini bakso super pedas merupakan penamaan unik dalam bentuk leksikal. Bakso menurut KBBI V (Daring) berarti makanan yanng terbuat dari daging, udang, ikan yang dicincang dan dilumatkan bersama tepung kanji dan putih telur, biasanya dibentuk bulat-bulat. Super menurut KBBI V (Daring) berarti lebih dari yang lain, luar biasa, dan istimewa. Pedas menurut KBBI V (Daring) berarti rasa seperti rasa cabai. Jadi bakso super pedas merupakan olahan makanan yang terbuat dari daging, dilumatkan bersama kanji, putih telur, cabai yang sudah dihaluskan, dan bahan-bahan yang lainnya setelah dibentuk bulat, kemudian dimasak hingga mengambang setelah itu ditiriskan. Bakso super pedas ini merupakan olahan pentol yang terasa sangat pedas, karena terdapat campuran cabai yang sudah dihaluskan didalam adonanya.

\section{SIMPULAN}

Penelitian ini dapat disimpulkan bahwa nama-nama menu makanan khusus bakso halal di media sosial google, facebook, dan instagram wilayah Denpasar-Bali yang ditemukan yaitu menggunakan tujuh penamaan. Peniruan bunyi dengan nama menu makanan pisang goreng kriuk. Penyebutan bagian dengan nama menu bakso tulangan. Penyebutan sifat khas dengan nama menu makanan yaitu bakso penyet. Penemu atau pembuat dengan nama menu makanan yaitu bakso mas Doel. Tempat asal dengan nama menu makanan yaitu bakso Solo. Bahan dengan nama menu makanan yaitu bakso lamtoro, bakso mozarela, dan bakso sawi hijau. Keserupaan dengan nama menu makanan yaitu bakso bomok dan bakso cinta. Pemendekan dengan nama menu makanan yaitu bakso BBQ. Penamaan baru dengan nama bakso super pedas. 


\section{DAFTAR RUJUKAN}

Amalia, F., \& Anggraeni, A.W. (2017). Semantik: Konsep dan Contoh Analisis. Malang : Madani.

Aminudin. (2016). Semantik : Pengantar Studi Tentang Makna. Bandung : Sinar Baru Algensindo.

Asrumi. (2017). Mengungkap di Balik Nama-nama Kuliner dan Implikasinya di Jember Jawa Timur (Tinjauan Sosiosemantik). Proceedings, The 1st International Confence on Education, Language, and Arts. ISSN 1699-1714. Dipetik September 26, 2019 dari

http://repository.unej.ac.id/handle/123456789/80339.

Chaer, A. (2013). Pengantar Semantik Bahasa Indonesia. Jakarta : Rineka Cipta.

Faisah. (2014). Nama Makanan dan Minuman Unik di Jember (Tinjauan Semantik). Skripsi. Tidak diterbitkan. Fakultas Keguruan dan Ilmu Pendidikan Bahasa dan Sastra Indonesia.

Faisah, Parto, \& Widjajanti, A. Nama Makanan dan Minuman Unik di Jember

(Tinjauan Semantik). dipetik Januari 5, 2020 dari https://scholar.googleusercontent.com/scholar?q=cache:1_XOanJ1RNYJ:sch olar.google.com/+faisah\&hl=id\&as_sdt=0,5

Gardjito, M., Hendrasty, H. K., \& Dewi, A. (2016). Industri Jasa Boga. Yogyakarta : Gadjah Mada University Press.

Komariah, K., Marwanti. (2010). Pemantapan dan Pengembangan Pengetahuan Menu dan Resep. Universitas Negeri Yogyakarta. Dipetik 1 Desember 2019 dari

http://staffnew.uny.ac.id/upload/131405892/pendidikan/MODUL+RESEP+DAN+MEN U+KONTINENTAL.pdf.

Mahsun. (2017). Metode Penelitian Bahasa : Tahapan, Strategi, Metode, dan Tekniknya. Depok : RajaGrafindo Persada.

Moleong, L. J. (2017). Metode Penelitian Kualitatif. Bandung: Remaja Rosdakarya Offset.

Mulyadi, J. (2019). Penamaan Tempat Usaha dan Menu Kuliner Spesifik Mi Pada Fitur GOO-FOOD dalam Aplikasi GO-JEK Area Padang : Kajian Semantik. Jurnal of Residu, Vol 3 (18, Juni), 50-63. Dipetik September 26, 2019 dari https://ojs.rcinstitut.id/index.php/education/article/download/211/181.

Sudaryanto. (2015). Metode dan Aneka Teknik Analisis Bahasa : Pengantar Penelitian Wahana Kebudayaan Secara Linguistis. Yogyakarta : Sanata Dharma University Press. 
Sugiono. (2017). Metode Peneletian Kuantitatif, Kualitatif dan $R$ \&D. Bandung: Alfabeta $\mathrm{Cv}$.

(2016). KBBI V Daring. Badan Pengembangan dan Pembinaan Bahasa, Kementrian Pendidikan dan Kebudayaan Republik Indonesia. 